\title{
ВІДТВОРЮВАЛЬНІ ЯКОСТІ СВИНОМАТОК ДАНСЬКОГО ТА ФРАНЦУЗЬКОГО ПОХОДЖЕННЯ В УМОВАХ ПРОМИСЛОВОГО КОМПЛЕКСУ
}

\author{
Михалко Олександр Григорович \\ аспірант спец. 204 ТВППТ \\ Сумський національний аграрний університет \\ ORCID ID: 0000-0002-0736-2296/ G-2305-2018 \\ Email: snau.cz@ukr.net
}

Повод Микола Григорович доктор сільськогосподарських наук, професор Сумський національний аграрний університет ORCID ID: 0000-0001-9272-9672/ W-1565-2018

Email: nic.pov@ukr.net

В статті порівняно відтворювальні якості свиноматок фрранцузької та данської селекції впродовж року в умовах одного господарства. Встановлено, що тварини данського походження мали в цей період на 16,02-18,73\% більшу потенційну багатоплідність. При цьому у них була на 1,07-1,57\% більша кількість мертвонароджених поросят. Вони виявили вищі на 15,13-17,70\% вищу багатоплідність та на 14,21-15,82\% кількість поросят при відлученні у порівнянні з їх ровеснииями фрраниузької селекції. В той же час свиноматки фрранцузького походження вирізнялись вищою на 7,75-14,52\% великоплідністю та більшою на 15,16-26,26 \% масою одного поросяти при відлученні. За масою гнізда поросят при народженні та при відлучені закономірної різниці між групами свиноматок різного походження не встановлено. Відтворювальні якості свиноматок як фрранцузького, так і данського походження залежали від змін пори року. Найменше від пори року залежали: багатоплідність - 3,68-4,37\%, збереженість поросят - 3,32-5,34\%, кількість поросят при відлучені - 5,406,83\%. В більшій мірі залежали від змін пори року індивідуальна маса поросят при відлучені - 11,28-13,34\% та маса гнізда поросят при відлученні - 12,74-17,49\%. Більшою сезонною мінливістю відрізнялись свиноматки данського походження. Найважчі поросята відлучались від свиноматок обох груп взимку, а найлегші - влітку. Маса гнізда поросят в обох групах була вищою в зимово-весняний період порівняно з літньо-осіннім. Встановлено значний вірогідний вплив генетичної належності свиноматок впродовж року на масу одного поросяти при відлучені на рівні 43,69\%, масу гнізда поросят при відлученні - 40,39\% та на багатоплідність - 19,13\%. Значно слабкіший вплив на ці показники чинила пора року, а саме: на масу гнізда поросят при відлучені - 4,87\%, на масу одного поросяти в при відлученні - 3,15\% та на збереженість поросят - 2,77\%. Не встановлено впливу пори року на багатоплідність. Взаємодія фокторів генетичної належності свиноматок та пори року мала значний вплив на багатоплідність - 47,22\%, масу одного поросяти при відлучені - 43,60\%, масу гнізда поросят при відлучені - 40,39\% та збереженість поросят - 2,77\%. Індекс комплексної оцінки відтворювальних якостей свиноматок був впродовж року вищим у тварин данського походження порівняно з поголів'ям фрранцузького походження на $11,47 \%$.

Ключові слова: свиноматка, порося, генотип, пора року, відтворювальні якості

DOI: https://doi.org/10.32845/bsnau.Ivst.2019.1-2.4

Подальший розвиток свинарства в сучасних умовах не можливий без удосконалення існуючих та розробки нових технологій вирощування, оптимізації годівлі тварин та повноцінного раціонального використання генофонду свиней в системах чистопородного розведення та гібридизації.

Дослідження В.Г. Пелиха [7] доводять, що в умовах інтенсивного виробництва свинини одним із головних фракторів, який обумовлює ефективність галузі, $€$ генетичний потенціал порід свиней та ступінь його реалізації. Породи свиней як селекційні надбання при правильному їх поєднанні забезпечуються отриманням високопродуктивних тварин. Більшість порід, які розводять в Україні, створені шляхом комбінування різних генотипів та збагачення і поліпшення генотипів місцевих порід, які добре пристосовані до зональних умов годівлі й утримання.

Відповідно до висновків Н.А. Попкова [10], нові типи свиней, створені в Україні в кінці XX століття, по продуктивності не змогли скласти конкуренцію тваринам західної селекції багато в чому через відставання в технології утримання та низького рівня годівлі, а також несумісного фінансування. 3 іншого боку імпортні тварини дуже складно адап-

туються до наших умов.

На думку В.П. Рибалко [11] продуктивність свиней і якість продукції свинарства залежить від генетичних особливостей, рівня й повноцінності годівлі, а також значною мірою від умов утримання, мікроклімату приміщень, в яких вони знаходяться, дотримання санітарних вимог.

Комбінація селекції в межах однієї країни з покращенням якості кінцевого продукту шляхом 3-х породного схрещування та ремонт маточного поголів'я у власному господарстві за рахунок утримання власної материнської породи і схрещування ії з іншою материнською породою 3 подальшим контролем отриманих молодих свинок - це, на думку німецького вченого X. Віллеке [2], є кращою можливістю для оптимізації виробництва свинини в сучасних умовах.

В.Д. Пилипець-Романюк [8] наголошує, що селекція в свинарстві неможлива без гібридизації, при якій застосовуються три форми гетерозису, найбільшого ефекту якого можна досягти при схрещуванні ліній, порід або груп тварин, відселекціонованих за різними ознаками, тобто які мають різний набір алелей різноманітних генів, що мають вплив на економічні показники. Таким чином, тільки завдяки принципу 
роздільної селекції можливе швидке вдосконалення вихідних порід, які в свою чергу успішно передаватимуть господарсько-корисні ознаки товарним гібридам.

На думку М.Г. Повода [9] використання для промислового схрещування кнурів термінальних генотипів європейської та американської селекції покращує відтворювальні показники свиноматок, а трипородне схрещування сприяє підвищенню відтворювальної здатності свиноматок на 11,2$12,17 \%$, а двопородне на 2,80-4,39 \%.

За твердженням В.Ф. Зєльдіна [4] при загальних принципах племінної роботи у тваринництві, селекційний процес у свинарстві має свої особливості через біологічні і господарсько-корисні ознаки свиней, які слід враховувати при їх розведенні. Сьогодні в Україні визначено напрямки генетичних методів поліпшення якісних показників у популяціях суб'єктами племінної справи і при цьому слід вважати пріоритетною саме індексну селекцію за незалежними рівнями.

Т.С. Коваленко [5] на основі аналізу типів успадкування основних селекційних ознак свиней встановив, що адитивний ефект дії генів в більшій мірі проявляється за великоплідністю $(13,33 \%)$ та живою масою гнізда на час відлучення (11,26\%). Материнський ефект більш високий за ознакою молочності маток $(5,49 \%)$ і збереженості поросят (6\%), а що стосується гетерозисного ефекту $(12,04 \%)$, то його прояв виявився переважно за ознакою багатоплідності.

На противагу іншим В.А. Лісний [6] додає, що одним 3 напрямків підвищення ефективності свинарства $€$ використання помісних маток в системі розведення. Переваги схрещування з використанням помісних маток полягають в тому, що вони не тільки дають гетерозисних нащадків, але й самі проявляють гетерозис за материнськими якостями. Отримане від такого схрещування потомство в більшій мірі успадковує ознаки батька, який використовувався на заключному етапі схрещування. Це створює сприятливу можливість для отримання помісного молодняку з високою відгодівельною та м'ясною продуктивністю.

D. Eyovwunu [13] отримав результати, які показують, що генотип в його дослідженні мав більш значний $(p<0,05)$ вплив на кількість поросят при народженні, вагу однієї голови при народженні, масу гнізда при відлученні, ніж сезонні фактори, а свиноматки великої білої породи переважали за показником багатоплідності аналогів порід дюрок та ландpac.

D.L. Kuhlers [17] стверджує, що поросята, отримані від схрещування помісних свиноматок дюрокхландрас та кнурів породи гемпшир, перевищували за індивідуальною масою на 0,05 кг при народженні та на 2,0 кг при відлученні поросят від свиноматок цього ж генотипу, але отриманих від запліднення кнурами порід дюрок та йоркшир. Однак, помісні поросята від маток дюрокхландрас та кнурів породи дюрок зростали в середньому на 0,028 кг/добу швидше з 56 днів до досягнення маси 100 кг і досягали її приблизно на 5 днів раніше, ніж поросята цих же свиноматок, схрещених 3 кнурами порід йоркшир та гемпшир.

За повідомленням P. Affentranger [12] вміст нежирного м'яса в тушах свиней вірогідно залежав від генотипу, а на споживання кормів та середньодобові прирости впливав насамперед режим годівлі.

В дослідженнях J. Hagan [14] встановлено, що на кількість поросят при народженні та відлученні, швидкість опоросу та масу поросят під час народження вірогідно впливали номер опоросу (репродуктивний цикл) та генотип, а вплив сезону із збільшенням номеру опоросу значно зменшував показник кількості поросят при народженні та відлученні.

Результати дослідів D. Knecht та K. Duziński [16] показали, що на репродуктивні параметри вірогідно впливає сезон та номер опоросу. Проте, найбільший вплив сезонних факторів був відмічений саме на масу поросят $(p<0,01)$. Номер опоросу мав менший вплив лише на кількість поросят при відлученні $(p<0,05)$. Порода також меншою мірою вплинула на кількість живих поросят при народженні та кількість поросят при відлученнні (p<0,05).

Дані досліджень Y.H. Huang [15] демонструють значний $(p<0,05)$ вплив породи на більшість досліджуваних репродуктивних параметрів, крім маси поросят при відлученні та інтервалу опоросу, а також виявляють, що номер опоросу має найсуттєвіший вплив на показники кількості живих поросят та кількість поросят при відлученні.

F. Mungate [18] вказує, що кількість поросят народжених живими була вищою, якщо свиноматки поросились в літні місяці, ніж у будь-який інший час року $(p<0,05)$. Найважчі поросята також народжувалися в той же період $(p<0,05)$, хоча вони не втримували перевагу у вазі до 21 дня та до настання терміну відлучення у віці 35 днів $(p<0,05)$. Гнізда поросят отримані від схрещування свиней порід гемпшир та дюрок, як правило, виявлялися кращими, ніж чистопородні їх аналоги порід ландрас або велика біла за показником кількості поросят при народженні.

Аналіз впливу факторів на високий вміст внутрішньом'язового жиру у свиней, проведений А. Sundruma та А. Aragona [19], встановив, що на цей показник більший вплив має режим годівлі, ніж генотип. Тому режим годівлі повинен бути більш пристосованим до генотипу поголів'я, використовуваному на фермі, та наявності обмежених ресурсів як за якістю свинини, так і з економічних причин.

За дослідженням Геті А.А. [3] важливу роль у підвищенні продуктивних якостей свиней одночасно із загальними паратиповими факторами відіграє і міжпородне схрещування та гібридизація, особливо за використання тварин зарубіжної селекції та подальшим їх відтворенням в умовах промислового виробництва в Україні.

Зважаючи на виявлену проблему недостатнього вивчення ефективного використання свиней іноземних генотипів в умовах індустріальних свинарських комплексів з урахуванням дії місцевих сезонних факторів, метою роботи стало порівняння продуктивних якостей свиноматок французької та данської селекції упродовж року.

Матеріали та методи досліджень. Для проведення дослідження використовувались дані продуктивності лактуючих свиноматок двох груп різного походження, що утримувались впродовж двох років в одному й тому ж маточнику підприємства, за однакових техніко-технологічних та об'ємно-планувальних рішень конструкцій, механізмів, устаткування та обладнання, також решта умов утримання були ідентичними впродовж вказаного часу.

До I (контрольної) групи було відібрано свиноматок генотипу $F_{1}$ Galaxy 900 французької компанії «France Hybrid», яких спаровували з кнурами лінії Maxter 304 тієї ж компанії. В II (дослідну) групу відбирались свиноматки $F_{1}$ селекції данської фрірми «DanAvl», яких осіменяли спермою

Вісник Сумського національного аграрного університету 
кнурів датського дюроку тієї ж фірми, відповідно до схеми гібридизації свинарського комплексу ТОВ «Агроінд» м. Підгородне Дніпропетровської області та утримували впродовж року.

За віком, живою масою, вгодованістю тварини в групах були аналогічними. Умови утримання і годівлі свиноматок під час холостого та поросного періоду були однакови- ми

Оцінка сезонної продуктивності свиноматок здійснювалась з врахуванням наступного часового розподілу: зима - 01.12-28.02; весна - 01.03-31.05; літо - 01.06 -13.09; осінь - 14.09-30.11. Відтворювальні якості свиноматок вивчали за загальноприйнятими методиками.

Схема досліду

Таблищя 1

\begin{tabular}{|l|c|c|}
\hline \multicolumn{1}{|c|}{ Показники } & \multicolumn{2}{|c|}{ Групи свиней } \\
\cline { 2 - 3 } & I (контрольна) & (дослідна) \\
\hline Генотип свиноматок & Galaxy 900 & 360 \\
\hline Кількість свиноматок у групі, гол. & 360 & дюрок \\
\hline Породність кнура & Maxter 304 & 3 \\
\hline Кількість кнурів, гол. & 3 & \\
\hline
\end{tabular}

Для комплексної оцінки відтворювальних якостей використали оціночний індекс за обмеженою кількістю ознак [1].

$$
I=B+2 W+35 G
$$

де: I - індекс відтворювальних якостей, балів;

В - кількість поросят при народженні, гол.;
W - кількість відлучених поросят, гол.;

G - середньодобовий приріст поросят при відлученHi, КГ

Результати досліджень. За результатами досліджень (табл. 2) встановлено відмінності в показниках відтворення у свиноматок взимку.

Таблиия 2

\section{Відтворювальні якості свиноматок $F_{1}$ різного походження при гібридизації} в умовах промислового комплексу взимку, $\mathrm{n}=360$

\begin{tabular}{|l|c|c|c|c|}
\hline \multicolumn{1}{|c|}{ Показник } & $\begin{array}{c}\text { I } \\
\text { (контрольна група) }\end{array}$ & $\begin{array}{c}\text { II } \\
\text { (дослідна група) }\end{array}$ & $\begin{array}{c}\text { Відносне } \\
\text { відхилення, \% }\end{array}$ & $\begin{array}{c}\text { Відхилення } \\
\text { II I }\end{array}$ \\
\hline Загальна кількість поросят при народженні, гол. & $12,67 \pm 0,36$ & $15,56 \pm 0,36^{* * *}$ & 18,57 & 2,89 \\
\hline Кількість мертвонароджених поросят, гол. & $0,47 \pm 0,06$ & $0,82 \pm 0,05^{* * *}$ & 42,83 & 0,35 \\
\hline Частка мертвонароджених поросят, \% & $4,70 \pm 0,71$ & $5,27 \pm 0,15$ & 29,79 & 1,57 \\
\hline Багатоплідність, голів & $12,22 \pm 0,31$ & $14,78 \pm 0,42^{* * *}$ & 17,32 & 2,56 \\
\hline Маса гнізда поросят при народженні, кг & $17,35 \pm 0,79$ & $18,33 \pm 0,71$ & 5,35 & 0,98 \\
\hline Великоплідність, кг & $1,42 \pm 0,04^{* * *}$ & $1,24 \pm 0,04$ & $-14,52$ & $-0,18$ \\
\hline Кількість поросят при відлученні, гол. & $11,62 \pm 0,15$ & $13,71 \pm 0,28^{* * *}$ & 15,24 & 2,09 \\
\hline Збереженість поросят, \% & $95,12 \pm 1,34^{* *}$ & $90,51 \pm 0,98$ & $-5,09$ & $-4,61$ \\
\hline Маса 1 голови при відлученні, кг & $8,09 \pm 0,12^{* * *}$ & $6,88 \pm 0,08$ & $-17,59$ & $-1,21$ \\
\hline Маса гнізда поросят при відлученні, кг & $94,01 \pm 1,04$ & $94,39 \pm 2,32$ & 0,40 & 0,38 \\
\hline Оціночний індекс, балів & 43,80 & 49,25 & 11,07 & 5,45 \\
\hline
\end{tabular}

Так в дослідній групі було отримано загальну кількість поросят при народженні 15,56 голів, що на 2,89 голови або на $14,52 \%(p<0,001)$ більше, ніж у контрольній. В гніздах поросят дослідної групи частка мертвонароджених поросят в середньому склала 5,27\%, тоді як у контрольній вона виявилась $4,70 \%$, що на 0,35 голови менше ( $p<0,001)$, ніж у дослідній.

Одночасно відслідковувалось перевищення свиноматок дослідної групи і за показником багатоплідності, яка досягла значення 14,78 гололови, що на 2,56 голови або на $17,32 \%$ перевищило ( $p<0,001)$ показники тварин контрольної групи.

За масою гнізда поросят при народженні спостерігалась тенденція до її підвищення на 0,98 кг або 5,35\% у свиноматок дослідної групи. Тоді як за великоплідністю поросята дослідної групи поступались аналогам контрольної - на $14,52 \%$ або 0,18 кг ( $p<0,001)$.

Середня збереженість поросят дослідної групи взимку зафіксована на рівні 90,51\%, що на 4,61\% (p<0,01) нижче показника контрольної.

Дослідження впливу генотипу на масу 1 голови при відлученні показало, що нижчою на 1,21 кг або 17,59\% $(p<0,001)$ вона була у дослідній групі порівняно з контрольною, тоді як за масою гнізда поросят при відлученні різниця була практично відсутньою.

За комплексом відтворювальних якостей, розрахованих з допомогою оціночного індексу, тварини дослідної групи взимку перевищували свиноматок контрольної групи на 5,45 балів, що склало $11,07 \%$.

Дослідження продуктивності піддослідного маточного поголів'я у весняний сезон (табл. 3) встановило, що, як і в попередню пору року, середня кількість поросят при народженні була вірогідно вищою у свиноматок дослідної групи. Це перевищення склало навесні 2,46 голови, що становило $16,02 \%$ ( $<<0,001)$. Також вірогідно на 0,27 голови, або на $33,40 \%(p<0,01)$ в цій групі виявилась і кількість мертвонароджених поросят, хоча відсоток мертвонароджених поросят не мав вірогідної різниці, але мав тенденцію до збільшення на $1,07 \%$ у свиноматок дослідної групи.

Як і взимку, багатоплідність свиноматок дослідної групи навесні виявилася вірогідно на 2,21 голову або 15,13\% вищою ( $<<0,001)$ у свиноматок дослідної групи порівняно 3 контрольною. Також в цій групі була вірогідно вищою на 2,17 кг $(11,51 \%)(p<0,05)$ маса гнізда поросят при народжені, хоч індивідуальна їх маса в цей період у свиноматок дослідної групи виявилась на 0,10 кг нижчою $(p<0,01)$ порівняно 3 цим показником у тварин контрольної групи. 
Відтворювальні якості свиноматок $F_{1}$ різного походження при гібридизації в умовах промислового комплексу весною, $\mathrm{n}=360$

\begin{tabular}{|l|c|c|c|c|}
\hline \multicolumn{1}{|c|}{ Показник } & $\begin{array}{c}\text { I } \\
\text { (контрольна група) }\end{array}$ & $\begin{array}{c}\text { II } \\
\text { (дослідна група) }\end{array}$ & $\begin{array}{c}\text { Biдносне } \\
\text { відхилення, \% }\end{array}$ & $\begin{array}{c}\text { Biдхилення } \\
\text { II } \pm \text { I }\end{array}$ \\
\hline Загальна кількість поросят при народженні, гол. & $12,90 \pm 0,36$ & $15,36 \pm 0,17^{* * *}$ & 16,02 & 2,46 \\
\hline Кількість мертвонароджених поросят, гол. & $0,53 \pm 0,06$ & $0,79 \pm 0,07^{* *}$ & 33,40 & 0,27 \\
\hline Частка мертвонароджених поросят, \% & $4,10 \pm 0,68$ & $5,17 \pm 0,18$ & 20,70 & 1,07 \\
\hline Багатоплідність, голів & $12,40 \pm 0,26$ & $14,61 \pm 0,19^{* * *}$ & 15,13 & 2,21 \\
\hline Маса гнізда поросят при народженні, кг & $16,68 \pm 0,69$ & $18,85 \pm 0,68^{*}$ & 11,51 & 2,17 \\
\hline Великоплідність, кг & $1,39 \pm 0,02^{* *}$ & $1,29 \pm 0,03$ & $-7,75$ & $-0,1$ \\
\hline Кількість поросят при відлученні, гол. & $11,71 \pm 0,22$ & $13,91 \pm 0,27^{* * *}$ & 15,82 & 2,2 \\
\hline Збереженість поросят, \% & $94,45 \pm 0,97^{*}$ & $91,77 \pm 0,56$ & $-2,92$ & $-2,68$ \\
\hline Маса 1 голови при відлученні, кг & $7,75 \pm 0,10^{* * *}$ & $6,73 \pm 0,10$ & $-15,16$ & $-1,02$ \\
\hline Маса гнізда поросят при відлученні, кг & $90,75 \pm 2,18$ & $93,78 \pm 2,66$ & 3,23 & 3,03 \\
\hline Оціночний індекс, балів & 43,77 & 49,23 & 11,09 & 5,46 \\
\hline
\end{tabular}

I хоча збереженість поросят до відлучення виявилась кращою на 2,68\% $(p<0,05)$ у гніздах свиноматок контрольної групи, в них на цей час, за рахунок нижчої багатоплідності, виявилось вірогідно на 2,20 голів (15,82\%) поросят менше $(p<0,001)$. В гніздах з меншою кількістю поросят, у свиноматок контрольної групи, індивідуальна їх маса виявилась вірогідно (p<0,001) на 1,02 кг або на 15,16\% вищою, тоді як за масою всього гнізда у них спостерігалась тенден- ція то її зменшення на 3,03 кг (3,23\%). Комплексний показник відтворювальних якостей, як і взимку, навесні виявився вищим на 5,46 балів, або на $11,09 \%$ у свиноматок дослідної групи.

Відмічаємо, що у літні місяці, попри зростання впливу зовнішніх сезонних факторів, які мали б теоретично знижувати загальну кількість поросят при народженні, цей показник мав деяке зростання (табл.4).

Таблиця 4

\section{Відтворювальні якості свиноматок $F_{1}$ різного походження при гібридизації} в умовах промислового комплексу влітку

\begin{tabular}{|l|c|c|c|c|}
\hline \multicolumn{1}{|c|}{ Показник } & $\begin{array}{c}\text { I } \\
\text { (контрольна група) }\end{array}$ & $\begin{array}{c}\text { II } \\
\text { (дослідна група) }\end{array}$ & $\begin{array}{c}\text { Відносне } \\
\text { відхилення, \% }\end{array}$ & $\begin{array}{c}\text { Відхилення } \\
\text { II } \pm \text { I }\end{array}$ \\
\hline Загальна кількість поросят при народженні, гол. & $13,06 \pm 0,29$ & $16,07 \pm 0,33^{* * *}$ & 18,73 & 3,01 \\
\hline Кількість мертвонароджених поросят, гол. & $0,62 \pm 0,05$ & $0,99 \pm 0,06^{* * *}$ & 37,14 & 0,36 \\
\hline Частка мертвонароджених поросят, \% & $4,78 \pm 0,65$ & $6,18 \pm 0,14^{*}$ & 22,65 & 1,4 \\
\hline Багатоплідність, голів & $12,46 \pm 0,46$ & $15,14 \pm 0,37^{* * *}$ & 17,70 & 2,68 \\
\hline Маса гнізда поросят при народженні, кг & $17,94 \pm 0,67$ & $19,53 \pm 0,65$ & 8,14 & 1,59 \\
\hline Великоплідність, кг & $1,44 \pm 0,02^{* *}$ & $1,29 \pm 0,05$ & $-11,63$ & $-0,15$ \\
\hline Кількість поросят при відлученні, гол. & $11,47 \pm 0,42$ & $13,37 \pm 0,39^{* *}$ & 14,21 & 1,9 \\
\hline Збереженість поросят, \% & $92,06 \pm 0,68^{* *}$ & $87,12 \pm 1,43$ & $-5,67$ & $-4,94$ \\
\hline Маса 1 голови при відлученні, кг & $7,27 \pm 0,18^{* *}$ & $6,07 \pm 0,25$ & $-19,77$ & $-1,2$ \\
\hline Маса гнізда поросят при відлученні, кг & $83,39 \pm 2,47$ & $81,74 \pm 4,79$ & $-2,02$ & $-1,65$ \\
\hline Оціночний індекс, балів & 42,69 & 47,85 & 10,80 & 5,16 \\
\hline
\end{tabular}

Отже, в дослідній групі, влітку отримано загальну кількість народжених поросят 16,07 голів, що на 3,01 голови $(18,73 \%)$ більше ніж в контрольній $(p<0,001)$. Також, як і в попередні пори року, в дослідній групі виявилась вірогідно вищою на 0,36 ( $<<0,001)$ голови і кількість мертвонароджених поросят, що обумовило і їх вищу на 1,4\% $(p<0,05)$ частку від загальної кількості народжених.

Як і в попередні пори року, у свиноматок данського походження виявилось вірогідно вища на 2,68 голови $(17,70 \%)$ багатоплідність $(p<0,001)$ та спостерігалась тенденція до збільшення на 1,59 кг маси гнізда поросят при народжені.

Вищою у тварин дослідної групи на 4,94\% (p<0,01) була і збереженість поросят до відлучення, та на 1,20 кг, або $19,77 \%$ (р<0,001) маса одного поросяти в цей період. Тоді як кількість поросят при відлученні виявилась на 1,90 голів $(14,21 \%)$ більшою у гніздах свиноматок цієї ж дослідної групи $(p<0,01)$.

Водночас, за масою гнізда поросят при відлучені ві- рогідної різниці у тварин контрольної та дослідної групи не встановлено, хоч і спостерігалась тенденція до їі підвищення на 1,65 кг, або 2,02\% у свиноматок французької селекції.

Різниця за результатом розрахунку оціночного індексу між тваринами різного походження влітку дещо зменшилась, але виявилась на 5,16 бали або на 10,80\% більшою у свиноматок данського походження.

Проведення аналітичної оцінки продуктивності піддослідних свиноматок в осінню пору року (табл. 5) показало, що загальна кількість поросят при народженні була вищою на 2,83 голови або18,53\%, ніж у тварин II (дослідної) групи порівняно 3 контрольною, де вона склала 12,44 голови $(\mathrm{p}<0,001)$.

Також у свиноматок данського походження виявилась більшою на 0,03 голів $(37,84 \%)$ і кількість мертвонароджених поросят $(p<0,01)$, тоді як частка мертвонароджених поросят у цій групі виявилась невірогідно вищою, ніж у контрольній на $1,23 \%$. 
Відтворювальні якості свиноматок $F_{1}$ різної селекції при гібридизації в умовах промислового комплексу восени, $\mathrm{n}=360$

\begin{tabular}{|l|c|c|c|}
\hline \multicolumn{1}{|c|}{ Показник } & $\begin{array}{c}\text { I } \\
\text { (контрольна група) }\end{array}$ & $\begin{array}{c}\text { Відносне } \\
\text { (дослідна група) }\end{array}$ & $\begin{array}{c}\text { Відхилення } \\
\text { відхилення, \% }\end{array}$ \\
\hline Загальна кількість поросят при народженні, гол. & $12,44 \pm 0,35$ & $15,27 \pm 0,13^{* *}$ & 18,53 \\
\hline Кількість мертвонароджених поросят, гол. & $0,49 \pm 0,07$ & $0,79 \pm 0,06^{* *}$ & 37,84 \\
\hline Частка мертвонароджених поросят, \% & $3,96 \pm 0,76$ & $5,19 \pm 0,13$ & 23,70 \\
\hline Багатоплідність, голів & $11,96 \pm 0,29$ & $14,52 \pm 0,14^{* * *}$ & 17,63 \\
\hline Маса гнізда поросят при народженні, кг & $16,39 \pm 0,68$ & $16,41 \pm 0,72$ & 0,12 \\
\hline Великоплідність, кг & $1,37 \pm 0,02^{*}$ & $1,26 \pm 0,04$ & $-8,73$ \\
\hline Кількість поросят при відлученні, гол. & $11,11 \pm 0,21$ & $13,02 \pm 0,21^{* * *}$ & 14,67 \\
\hline Збереженість поросят, \% & $92,97 \pm 1,77$ & $88,68 \pm 1,63$ & $-0,11$ \\
\hline Маса 1 голови при відлученні, кг & $7,79 \pm 0,08^{* * *}$ & $6,17 \pm 0,29$ & $-2,84$ \\
\hline Маса гнізда поросят при відлученні, кг & $-4,29$ & $-26,26$ \\
\hline Оціночний індекс, балів & $86,62 \pm 2,17$ & $80,34 \pm 4,99$ & $-7,82$ \\
\hline
\end{tabular}

Показник багатоплідності свиноматок дослідної групи восени склав 14,52 голови, тоді як аналогічний показник в контрольній групі склав 11,96 голів, що нижче ніж у дослідній на $17,63 \%$ або 2,56 голів ( $<<0,001)$.

За масою гнізда поросят при народженні між тваринами контрольної та дослідної групи різниця була практично відсутньою.

Однак, маса одного поросяти при народженні була вищою у контрольній групі на 8,73\% $(0,11$ кг) $(p<0,05)$ і склала 1,37 кг.

Збереженість поросят восени виявилась як і в попередні пори року нижчою у свиноматок данського походження і склала 88,68\%, що невірогідно на 4,29\% нижче аналогічного показника тварин французького походження.

Maca 1 поросяти при відлученні у 28 діб виявилась вищою у I групі і склала 7,79 кг, що на 1,62 кг, або на 26,26\% ( $p<0,001)$ вище, ніж у дослідній. Тоді як за масою гнізда поросят при відлученні вірогідної різниці не встановлено, хоч і простежувалась тенденція до її підвищення на 6,28 кг, або на 7,82\% у свиноматок контрольної групи.

Комплексний показник відтворювальних якостей, розрахований як оціночний індекс, восени виявився найнижчим, але був на 4,49 бали або на 9,62\% вищим у тварин дослідної групи.

Таким чином, порівняння відтворювальної продуктивності свиноматок французького та данського походження в ідентичних умовах утримання та годівлі показало, що тварини данського походження мали впродовж року на 16,02-
18,73\% більшу потенційну багатоплідність, при цьому у них було на 1,07-1,57\% більша кількість мертвонароджених поросят. Вони виявили на 15,13-17,70\% вищу багатоплідність та на 14,21-15,82\% вищу кількість поросят при відлучені в порівнянні з їх ровесницями французької селекції. В той же час свиноматки французького походження вирізнялись вищою на 7,75-14,52\% великоплідністю та більшою на $15,16-26,26 \%$ масою одного поросяти при відлученні. За масою гнізда поросят при народженні та при відлученні закономірної різниці між групами свиноматок різного походження не встановлено. Комплексний показник відтворювальних якостей свиноматок, розрахований як оціночний індекс за обмеженою кількістю ознак виявився вищим на 9,62-11,09 \% у свиноматок данського походження.

Динаміка показника багатоплідності піддослідних свиноматок (рис. 1) вказує на відсутність вірогідної різниці між його значенням в різні періоди року як в контрольній, так і в дослідній групах. Тенденції зміни цього показника у свиноматок французького походження (контрольної групи) впродовж року показують, що взимку вона досягла значення в 12,22 голів, відносно якого невірогідно зросла весною на 0,18 голів та влітку на 0,24 голови, але невірогідно знизилась осінню на 0,26 голови. Аналіз динаміки багатоплідності тварин данського походження (дослідної групи) демонструє його зимове значення на рівні 14,78 голів, порівняно з яким цей показник був недостовірно нижчим у весняний та осінній сезони на 0,17 та 0,26 голів відповідно і також недостовірно вищим на 0,36 голів - влітку.

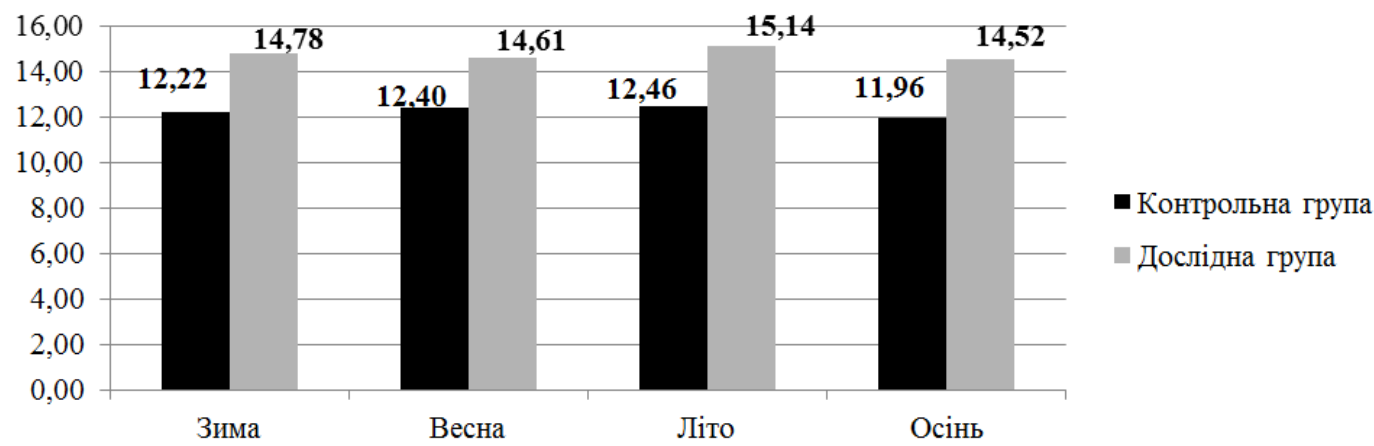

Puc. 1 Динаміка показника багатоплідності свиноматок впродовж року

Дослідження збереженості поросят відобразило тенденцію до ії̈ покращення в зимово-весняний період в обох групах та до стрімкого погіршення в осінньо-літній період у дослідній групі (рис 2). При цьому збереженість поросят в контрольній групі взимку виявилась на рівні 95,12\%, весною - невірогідно нижче цього значення на 0,67\%, літом - вірогідно ( $p<0,05)$ нижче на $3,06 \%$ та осінню - знову невірогідно нижче на 2,15\%. Збереженість поросят дослідної групи була 
менш мінливою і варіювала від максимального значення весною 91,77\%, до мінімального влітку - 87,12\%. Зимове значення цього показника невірогідно нижче весняного на
$1,26 \%$, та вірогідно на 3,39\% $(p<0,05)$ вище літнього і невірогідно на 1,83\% вище порівняно з осінню.

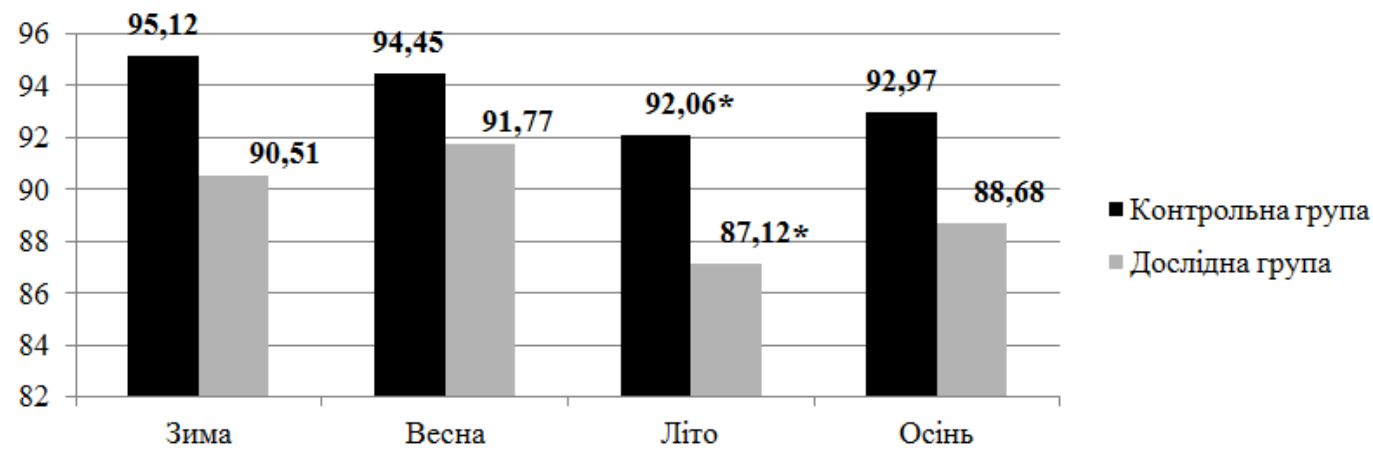

Puc. 2 Динаміка збереженості поросят впродовж року

Кількість відлучених поросят залежить як від багатоплідності, так і від їх збереженості. Вивчення динаміки значень показника кількості відлучених поросят впродовж чотирьох досліджуваних пір року показує, що у свиноматок контрольної групи (французького походження) не встановлено вірогідних його змін в період від зими до літа (рис 3). В зи- мові місяці цей показник склав 11,62 голів та мав тенденцію до підвищення на 0,09 голови весною і зниження на 0,15 голів влітку. Тоді як восени він достовірно $(p<0,05)$ знизився на 0,51 голови порівняно із зимою, на 0,60 голови порівняно з весною та на 0,36 голови - $з$ літом.

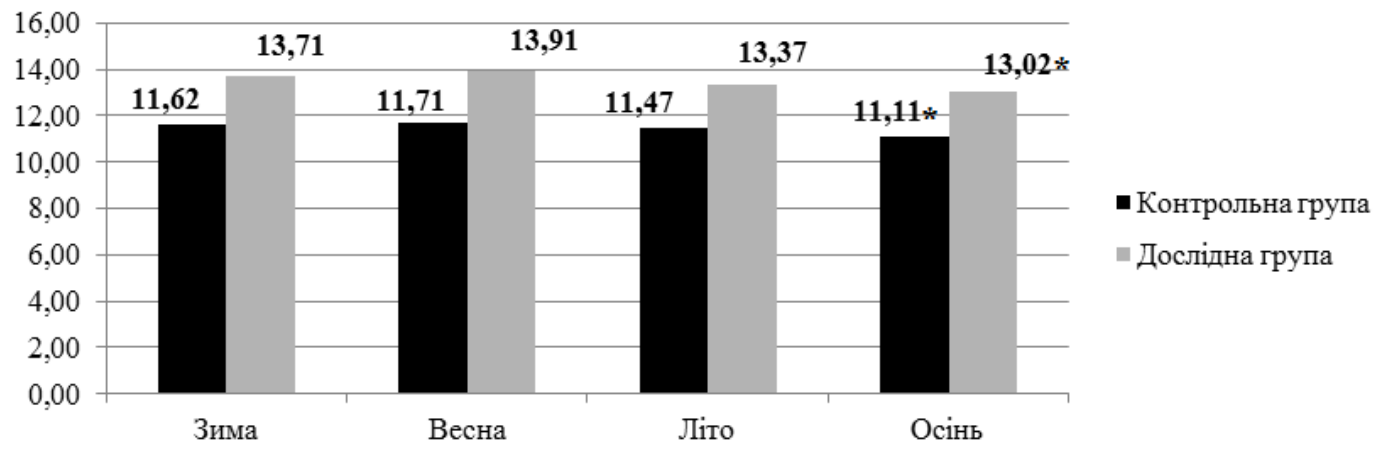

Puc. 3 Динаміка кількості відлучених поросят впродовж року

У свиноматок дослідної групи (данського походження) спостерігалась аналогічна тенденція. Найбільша кількість поросят при відлученні в цій групі виявлена навесні 13,91 голови, тоді як в зимові місяці в середньому відлучали недостовірно на 0,2 голови, а влітку - на 0,54 голови менше відносно весняних показників. Восени, як і в контрольній групі, спостерігалось вірогідне зменшення кількості поросят при відлученні на 0,69 голів порівняно із зимою $(p<0,05)$, на 0,89 голів $(p<0,01)$ - 3 весною та 0,35 голів - 3 літом.

Аналіз динаміки маси однієї голови при відлученні у
28 діб вказує на його незначне зниження в літній період в обох групах (рис. 4) та зростання його в зимову та весняну пори року. При цьому в контрольній групі ці коливання відносно зими були менш суттєвими й різниця в масі однієї голови при відлученні між показником зимою та весною склала 0,34 кг (p<0,05), зимою та літом - 0,82 кг ( $<<0,001)$, зимою та осінню - 0,30 кг $(p<0,05)$. Водночас в дослідній групі ця різниця зимових значень з весною склала 0,15 кг, з літом - 0,81 кг $(p<0,01)$ та з осінню - 0,71 кг $(p<0,01)$.

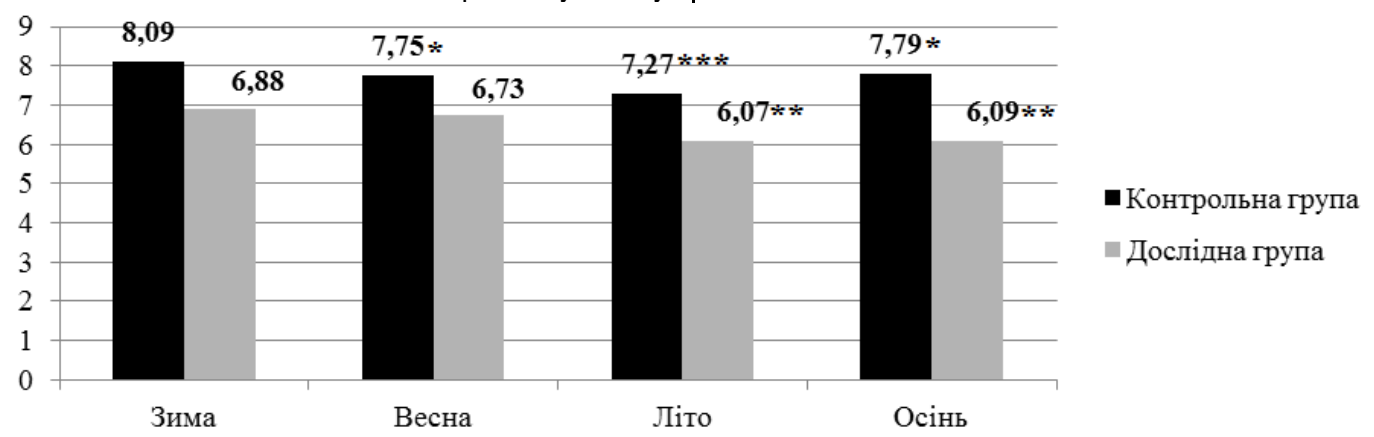

Рuc. 4 Динаміка показника маси одного поросяти при відлученні впродовж року

Маса гнізда поросят синтезується з показників їх кі- | лькості та індивідуальної маси при відлученні. Узагальнення 
даних про річні зміни показника маси гнізда поросят при відлученні показало, що в обох групах він був стабільно вищим впродовж зимово-весняного періоду. При цьому в контрольній групі ці коливання відносно зими були менш суттєвими: 3,26 кг, 10,62 кг (р<0,001), 7,39 кг ( $р<0,01)$ - в порівняні весна, літо, осінь. В дослідний групі маса гнізда поросят при відлучені зимою склала 94,39 кг, що більше на 0,61 кг порівняно з весною, на 12,65 кг $(p<0,01)$ порівняно 3 літом та на 14,05 кг $(p<0,01)$ в порівнянні з осінню.

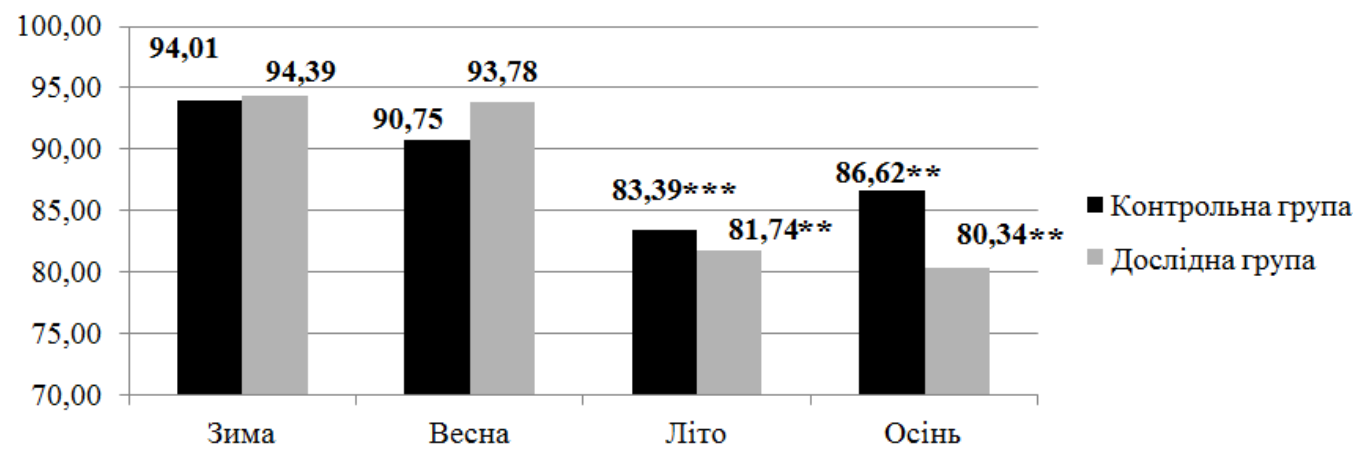

Puc. 5 Динаміка зміни маси гнізда поросят при відлученні впродовж року

Таким чином, відтворювальні якості свиноматок як французького, так і данського походження залежали від пори року. Із досліджуваних факторів найменш залежала від пори року багатоплідність. В контрольній групі динаміка викликана порою року склала від 11,96 до 12,40 голів або $3,68 \%$. В дослідній групі ці коливання склали 4,27\% від 14,52 до 15,14 голови. Найнижчим цей показник виявився восени, а найвищим влітку.

Збереженість поросят до відлучення також залежала від змін сезонів року. Найкращою вона виявилась в обох групах в зимово-весняний період, а найнижчою в літньоосінній. У свиноматок французького походження річні зміни цього показника склали 3,32\%: від 92,06\% влітку до 95,12\% взимку. У тварин данського походження цей показник коливався на 5,34\%: від 87,12 до 91,77\%. Встановлено залежність кількості поросят при відлученні від пори року. В контрольній групі ці коливання склали 5,40\%: від 11,11 до 11,71 голови, тоді як в дослідній 6,83\%: від 13,02 до 13,91 голови. Найменше відлучалось поросят в обох групах восени.

Найважчі поросята відлучались від свиноматок обох груп взимку, а найлегші - влітку. У контрольній групі ця різниця склала $11,28 \%$, а в дослідній 13,34\%.

Маса гнізда поросят також залежала від пори року і в обох групах була вищою в зимово-весняний період порівняно з літньо-осіннім. У контрольній групі сезонні коливання склали 12,47\%: від 83,39 до 94,01 кг, тоді як в дослідній 17,49\%: від 80,34 до 94,39 кг. Тобто, відтворювальні показники свиноматок обох генотипів залежали від змін пори року. Найменше від них залежали: багатоплідність - 3,684,37\%, збереженість поросят до відлучення - 3,32-5,34, кількість поросят при відлученні - 5,40-6,83\%, У більшій мірі залежали від змін пори року: індивідуальна маса поросят при відлучені - 11,28-13,34\% та маса гнізда поросят в цей період - 12,74-17,49\%. Більшою сезонною мінливістю відрізнялись свиноматки данського походження.

Шляхом двофакторного дисперсійного аналізу визначали силу впливу генетичної належності свиноматок та пори року, в яку проходив опорос на зміни основних показників відтворювальної якості. За нашими розрахунками вплив сезону опоросу виявився статистично не значимим і

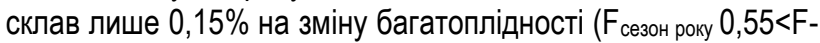
критичне 2,63). Фактор генотипу тварин виявився статистично

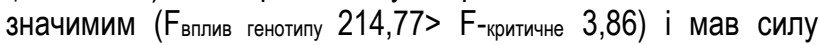
впливу на багатоплідність в межах 19,13\%. Вплив взаємодії

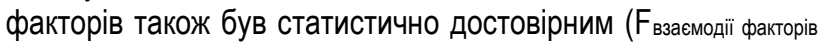
176,7> F-критичне 2,63) і встановився на рівні 47,22\% від впливу всіх фракторів. У той же час дія неврахованих факторів спричинила зміну показника багатоплідності поросят із силою впливу $33,50 \%$ (рис. 6).

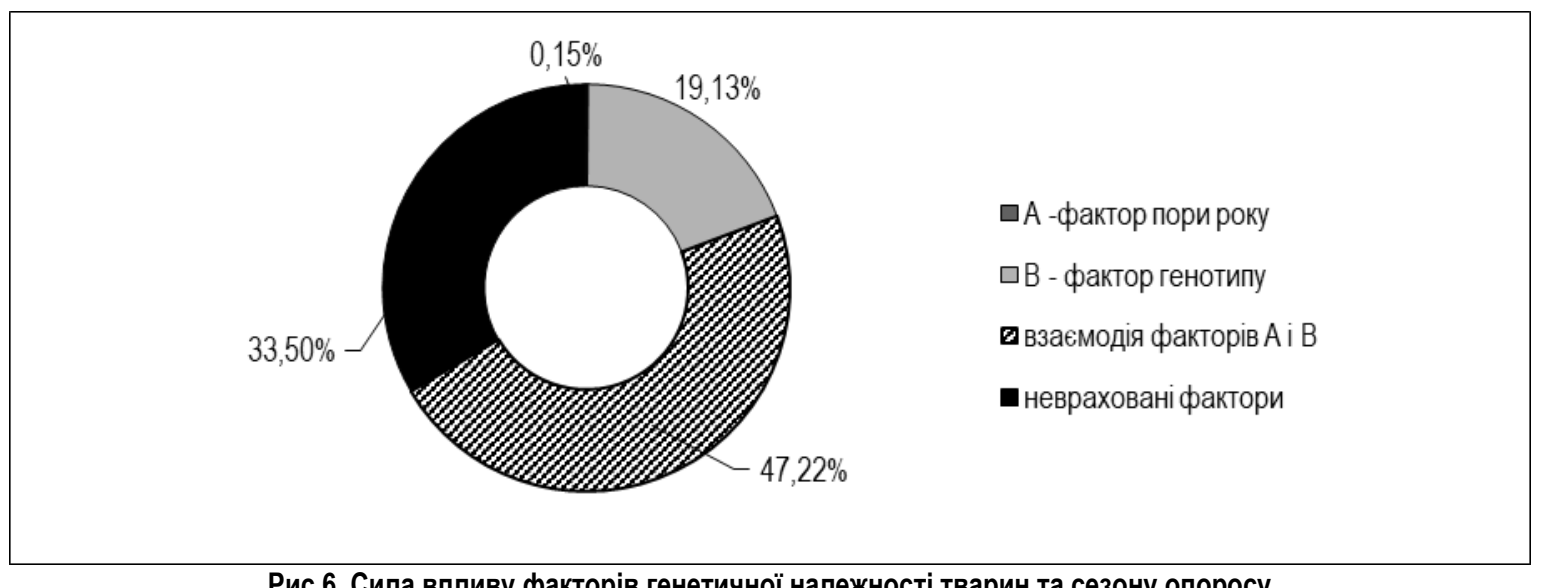

Рис.6. Сила впливу факторів генетичної належності тварин та сезону опоросу на багатоплідність

Результати впливу сезону року та генотипу на збе- | реженість поросят виявилися статистично достовірними 


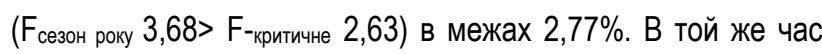
фактор впливу генетичної належності свиноматок на збереженість не набрав статистичної достовірності ( $F_{\text {фактор генотипу }}$ 0,07< F-критичне 2,63) і вплинув на показник збереженості 3 силою всього 0,02\%. Вплив взаємодії факторів сезону року та генотипу на збереженість був статистично достовірним

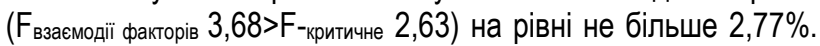
Невраховані фактори спричинили зміну показника збереженості поросят із силою впливу $94,43 \%$ (рис. 7).

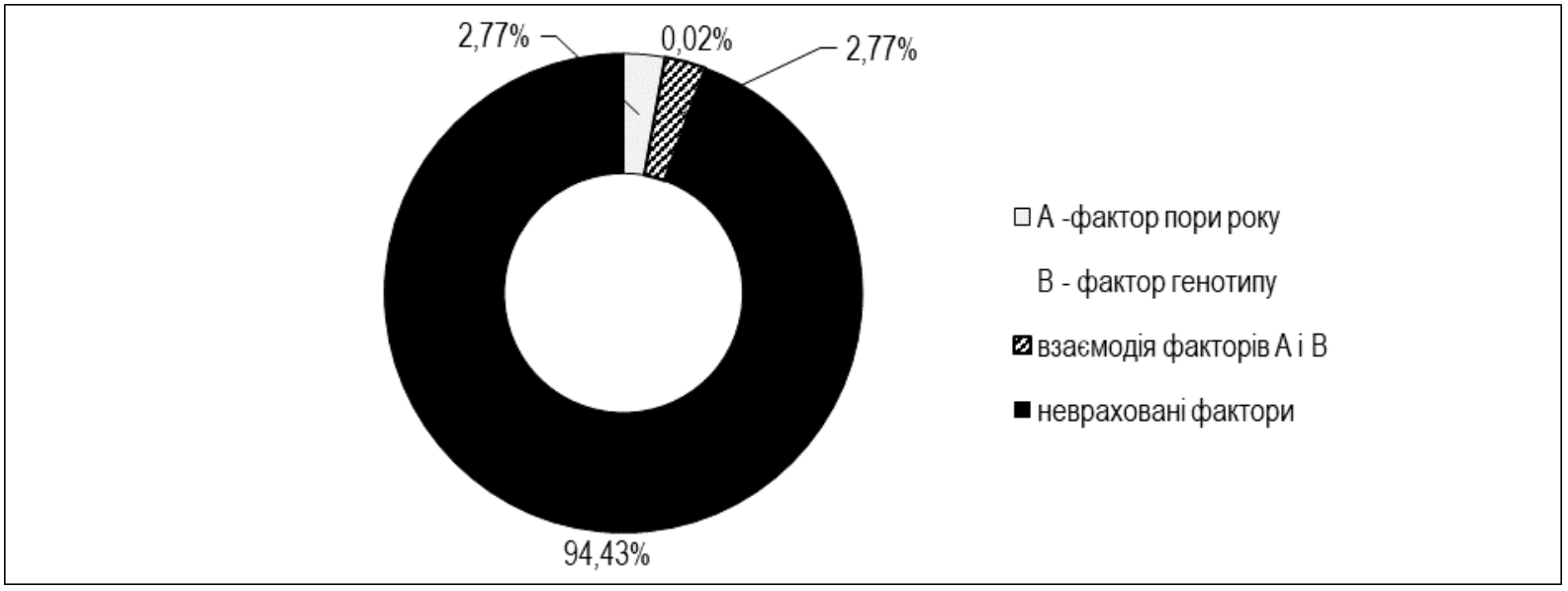

Рис.7 Сила впливу факторів генетичної належності тварин та сезону опоросу на збереженість поросят

Двофакторний аналіз показав, що вплив пори року та вплив генотипу тварин на масу однієї голови при відлученні у 28 діб виявилися статистично значимими $\left(F_{\text {пора року }} 7,90>\mathrm{F}\right.$ -

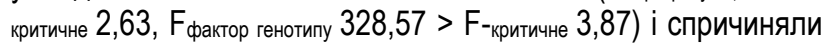
зміну досліджуваного показника в межах 3,15\% та 43,69\% відповідно. Вплив взаємодії факторів сезону року та геноти-

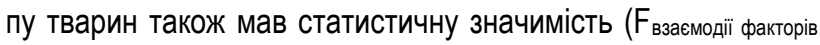

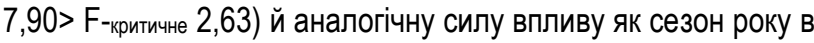
межах $3,18 \%$. Невраховані фактори спричинили зміну показника маси однієї голови при відлученні з силою впливу $50,00 \%$ (Рис. 8).

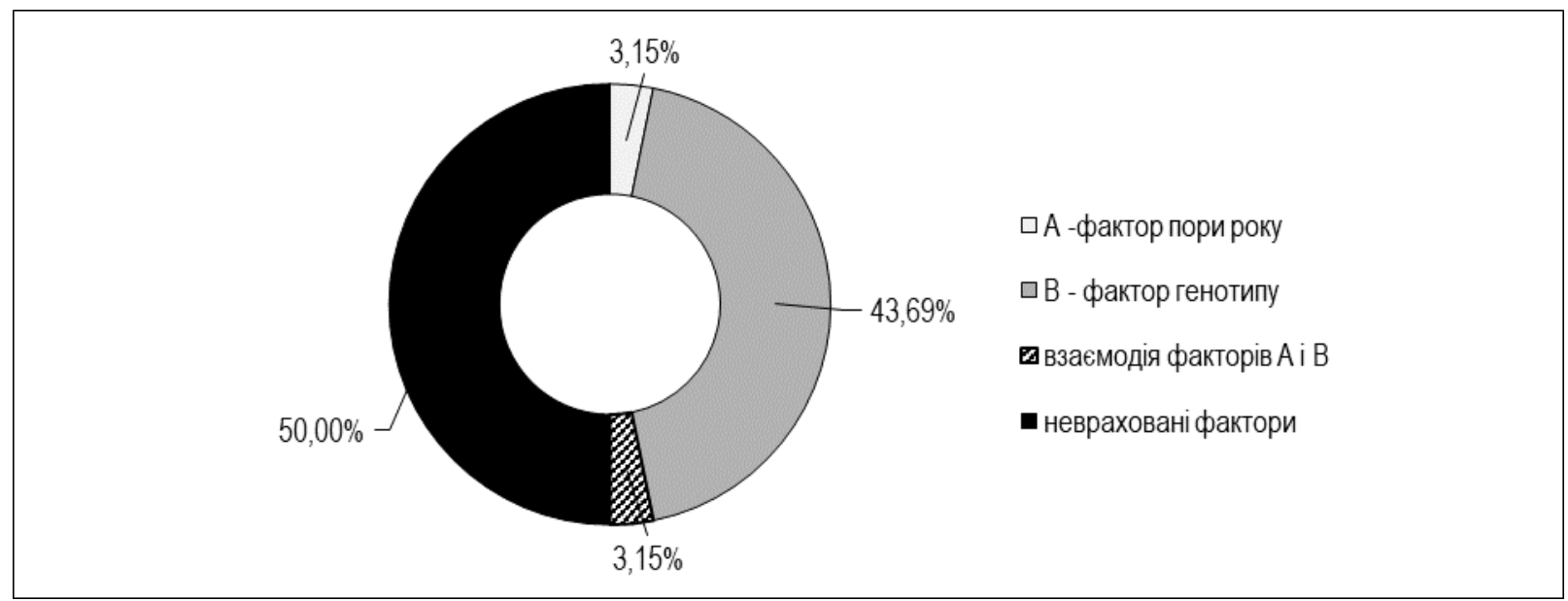

Рис.8. Сила впливу факторів генетичної належності тварин та сезону опоросу на масу одного поросяти при відлученні у 28 діб

Дослідження впливу факторів, що вивчались, і їх взаємодії на масу гнізда при відлученні у 28 діб виявилися

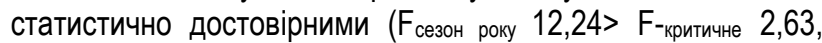

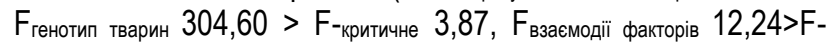
критичне 2,63) та здійснювали плив на зміну даного показника в межах 4,87\%, 40,39\% та 4,87\% відповідно. В той же час невраховані фрактори спричинили зміну показника маси гнізда поросят при відлученні з силою впливу 49,86\% (рис. 9). 


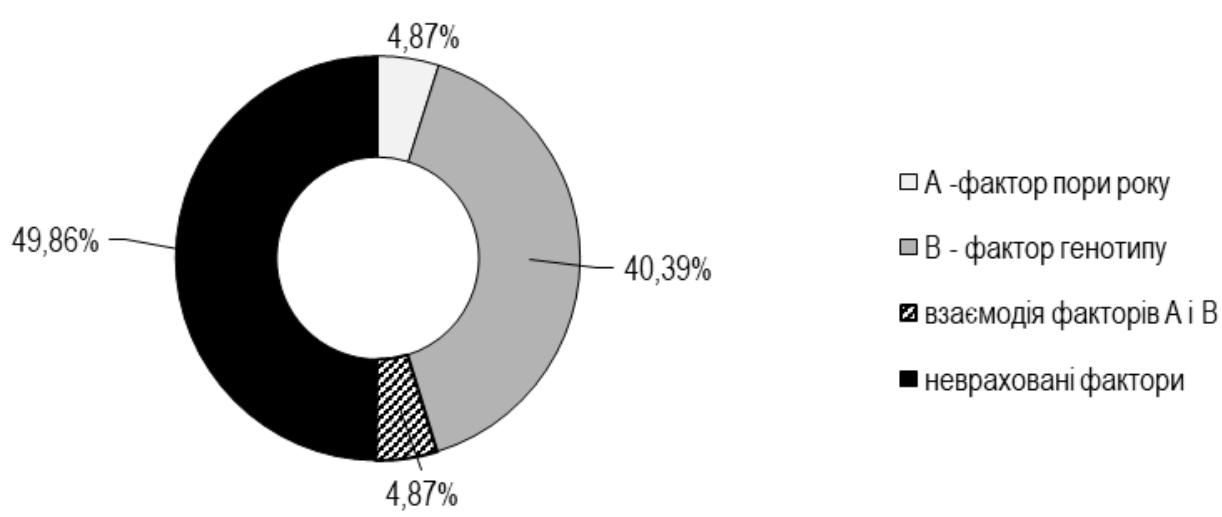

Рис.9 Сила впливу факторів генетичної належності тварин та сезону опоросу на масу гнізда поросят при відлученні

Обговорення результатів дослідження.

Наявність встановленого нами вірогідного впливу сезону року на відтворювальні якості свиноматок підтверджується висновками J. Hagan [14] та Y.H. Huang [15].

Найбільш сильний вплив сезонних факторів нами, як i D. Knecht, K. Duziński [16] та Y.H. Huang [15], був виявлений саме на показник маси поросят при відлученні.

Однак, знайдений нами достовірний вплив генотипу свиноматок на кількість поросят народжених живими та кількість відлучених поросят був суттєвішим за інші фрактори (19,13-43,69\%), що не співпадає з висновками D. Knecht та K. Duziński [16], які наголошують на незначній дії цього фактора на вказані показники.

Дослідження впливу сезону року на частку мертвонароджених поросят показало, що кількість поросят народжених живими була вищою в осінні місяці, а це суперечить твердженням F. Mungate [18], який в результатах свого досліду говорить про найменшу кількість мертвонароджених поросят в літній сезон.

Висновки.

1. Свиноматки данського походження мали більшу загальну кількість поросят при народжені, вищу багатоплідність, більшу кількість поросят при відлученні та більшу кількість мертвонароджених поросят. У той же час свиноматки французького походження вирізнялись вищою великоплідністю та більшою масою одного поросяти при відлучені. За масою гнізда поросят при народженні та при відлученні закономірної різниці між групами свиноматок різного походження не встановлено.

2. Відтворювальні якості свиноматок як фрранцузько- го, так і данського походження залежали від змін пори року. Найменше від них залежали: багатоплідність, збереженість поросят до відлучення, кількість поросят при відлученні. У більшій мірі залежали від змін пори року індивідуальна маса поросят при відлученні та маса гнізда поросят в цей період. Більшою сезонною мінливістю відрізнялись свиноматки данського походження.

3. Встановлено значний вірогідний вплив генетичної належності свиноматок на масу одного поросяти при відлученні 43,69\%, масу гнізда поросят в цей період 40,39\% та на багатоплідність 19,13\%. Значно слабкіший вплив на ці показники чинила пора року - на масу гнізда поросят при відлучені $4,87 \%$, масу одного поросяти в цей період $3,15 \%$ та на збереженість поросят 2,77\%.

4. Індекс комплексної оцінки відтворювальних якостей свиноматок був впродовж року вищим у тварин данського походження порівняно з поголів'ям фрранцузького походження на $11,47 \%$.

5. Із досліджень випливає, що поросята французької селекції, народжуючись у меншій кількості, мали більшу масу 1 голови й майже рівну поросятам данського походження масу гнізда при відлученні, що свідчить про генетичний резерв більш високої енергії їх росту та вищої адаптаційної здатності, який потенційно можливо використовувати для підвищення ефективності виробництва свинини.

Перспективи подальших досліджень. Вважаємо за доцільне провести вивчення інтенсивності росту та відгодівельних якостей свиней французького і данського походження в геокліматичних умовах України.

\section{Список використаної літератури:}

1. Березовский Н.Д., Почерняев Ф.К., Коротков В.А. Методика моделирования индексов для использования их в селекции свиней. Методы улучшения процессов селекции, разведения и воспроизводства свиней (методические указания). M., 1986. C. $3-14$.

2. Віллеке X. Селекция на службе у производства. Современное свиноводство. Актуальные статьи специализированного немецкого журнала. Фастов. Юнивест принт, 2007. С. 42 - 44.

3. Гетя А.А. Організація селекційного процесу в сучасному свинарстві: монографія. Полтава: Полтавський літераmop, 2009. $192 \mathrm{c}$.

4. Зєльдін В.Ф. Особливості селекційної роботи у свинарстві. Розведення і генетика тварин, 2017. Вип. 53. С. 119 -

5. Коваленко Т.С. Удосконалення оцінки продуктивних і племінних якостей свиней за селекційними індексами: автореф. дис. на здобуття наук. ступеня канд. с.-г. наук: спец. 06.02 .01 - розведення та селекція тварин. В.Г. Пелих. Полтава, 2011. 23 c. 
6. Лісний В.А. Отримання багаторазового гетерозиса в свинарстві. Таврійський науковий вісник. Вип. 11, частина 2 том 1. Херсон, 1999. С. $79-83$.

7. Пелих В.Г., Чернишов І.В., Левченко М.В. Генофонд м'ясних порід та перспективи його використання в свинарстві. Таврійський науковий вісник. Вип. 78. частина 2 том 1. Херсон, 2012. С. 160 - 165.

8. Пилипець-Романюк В.Д. Особливості селекції свиней. Сучасне тваринництво, 2011. URL:http://agrobusiness.com.ua/agro/suchasne-tvarynnytstvo/item/8012-osoblyvosti-selektsii-svynei.html

9. Повод М.Г., Бондаренко М.С., Грищенко С.М. Відтворювальні якості свиней різного походження. Науковотехнічний бюлетень, 2015. № 114. С. $132-136$.

10. Попков Н.А., Шейко И.П. О вопросе целесообразности завоза мясных генотипов свиней в Республике Беларусь. Зоотехническая наука Беларуси: Сб. науч. тр. РУГ1 НПЦ АНБ по животноводству. Жодино, 2011. Т. 46. С. 3 - 7.

11. Рибалко В.П., Флока Л.В. Вплив фенотипових фракторів на продуктивні якості свиней червоно-білопоясої породи: монографія. Полтава: РВВ ПУЕТ, 2013. 152 с.

12. Affentrangera, P., Gerwiga, C., Seewera, G.J.F., Schwörerb, D., and Künzia, N., 1996. Growth and carcass characteristics as well as meat and fat quality of three types of pigs under different feeding regimens. Livestock Production Science, issues 2-3, Vol. 45, pp. $187-196$.

13. Eyovwunu, D., Omeje, S.I. and Akpodiete, J. O., 2016. Effects of genotype on the reproductive traits of the female pigs. IOSR Journal of Agriculture and Veterinary Science, issue 3, Vol. 9, Ver. I, pp. 20 - 22.

14. Hagan, J., 2018. The effects of breed, season and parity on the reproductive performance of pigs reared under hot and humid environments. Tropical Animal Health and Production, issue 51(4), p. 52. DOI: 10.1007/s11250-018-1705-5.

15. Huang, Y.H., Lee, Y.P., Yang, T.S. and Roan, S.W., 2003. Effects of Sire Breed on the Subsequent Reproductive Performances of Landrace Sows. Asian Australasian Journal of Animal Sciences, issue 16 (4), p. 7. DOI:10.5713/ajas.2003.489.

16. Knecht, D., Srodon, S. and Duziński, K., 2015. Breed on selected reproductive performance parameters of sows. Arch. Anim. Breed, issue 58, pp. $49-56$.

17.Kuhlers, D.L., Jungst, S.B. and Little, J.A., 1989. Comparisons of specific crosses from Duroc-Landrace, YorkshireLandrace and Hampshire-Landrace sows managed in two types of gestation systems: pig performance. J Anim Sci., issue 67 (10), pp. $595-602$.

18. Mungate, F., Dzama, K., Mandisodza, K. and Shoniwa, A., 2009. Some non-genetic factors affecting commercial pig production in Zimbabwe. South African Journal of Animal Science, Vol. 29. DOI:10.4314/sajas.v29i3.44202.

19. Sundruma, A., Aragona, A., Schulze-Langenhorstb, C., Bütferingb, L., Henningc, M. and Stalljohannb, G., 2011. Effects of feeding strategies, genotypes, sex, and birth weight on carcass and meat quality traits under organic pig production conditions. NJAS - Wageningen Journal of Life Sciences. issues 3-4, Vol. 58, pp. 163 - 172. DOl.org/10.1016/j.njas.2011.09.006.

\section{References:}

1. Berezovskiy, N.D., Pochernyaev, F.K. and Korotkov, V.A., 1986. Metodika modelirovaniya indeksov dlya ispolzovaniya ih v selektsii sviney [Methodology for modeling indices for use in breeding pigs]. Metodyi uluchsheniya protsessov selektsii, razvedeniya $\mathrm{i}$ vosproizvodstva sviney (metodicheskie ukazaniya), pp. 3 - 14.

2. Villeke, H., 2007. Selektsiya na sluzhbe u proizvodstva [Breeding in the service of production]. Sovremennoe svinovodstvo. Aktualnyie stati spetsializirovannogo nemetskogo zhurnala, pp. $42-44$.

3. Hetia, A.A., 2009. Orhanizatsiia selektsiinoho protsesu v suchasnomu svynarstvi: monohrafiia [Organization of breeding process in modern pig breeding: a monograph]. Poltava: Poltavskyi literator, $192 \mathrm{p}$.

4. Zieldin, V.F., 2017. Osoblyvosti selektsiinoi roboty u svynarstvi [Features of breeding work in pig breeding]. Rozvedennia $i$ henetyka tvaryn, issue 53, pp. $119-124$.

5. Kovalenko, T.S., 2011. Udoskonalennia otsinky produktyvnykh i pleminnykh yakostei svynei za selektsiinymy indeksamy [Improving the assessment of productive and breeding qualities of pigs by breeding indices]. Dissertation author's abstract, $23 \mathrm{p}$.

6. Lisnyi, V.A., 1999. Otrymannia bahatorazovoho heterozysa v svynarstvi [Obtaining multiple heterosis in pig breeding]. Tavriiskyi naukovyi visnyk, issue 11, vol. 1, pp. $79-83$.

7. Pelykh, V.H., Chernyshov, I.V. and Levchenko, M.V., 2012. Henofond miasnykh porid ta perspektyvy yoho vykorystannia v svynarstvi [Meat gene pool and prospects for its use in pig production]. Tavriiskyi naukovyi visnyk, issue 78, vol. 1, pp. 160 - 165.

8. Pylypets-Romaniuk, V.D., 2011. Osoblyvosti selektsii svynei [Features of pig breeding]. Suchasne tvarynnytstvo, URL:http://agro-business.com.ua/agro/suchasne-tvarynnytstvo/item/8012-osoblyvosti-selektsii-svynei.html

9. Povod, M.H., Bondarenko, M.S. and Hryshchenko, S.M., 2015. Vidtvoriuvalni yakosti svynei riznoho pokhodzhennia [Reproductive qualities of pigs of different origin]. Naukovo-tekhnichnyi biuleten, issue 114, pp. $132-136$.

10. Popkov, H.A. and Sheyko, I.P., 2011. O voprose tselesoobraznosti zavoza myasnyih genotipov sviney v Respublike Belarus [About the advisability of importing meat genotypes of pigs in the Republic of Belarus]. Zootehnicheskaya nauka Belarusi: Sb. nauch. tr. RUG1 NPTs ANB po zhivotnovodstvu, issue 46, pp. $3-7$.

11. Rybalko, V.P. and Floka, L.V., 2013. Vplyv fenotypovykh faktoriv na produktyvni yakosti svynei chervono-bilopoiasoi porody: monohrafiia [Influence of phenotypic factors on the productive pigs of chervono bilopoyaso breed: monograph]. Poltava: RVV PUET, $152 \mathrm{p}$.

12. Affentrangera, P., Gerwiga, C., Seewera, G.J.F., Schwörerb, D., and Künzia, N., 1996. Growth and carcass characteristics as well as meat and fat quality of three types of pigs under different feeding regimens. Livestock Production Science, issues 2-3, Vol. 45, pp. $187-196$.

13. Eyovwunu, D., Omeje, S.I. and Akpodiete, J. O., 2016. Effects of genotype on the reproductive traits of the female pigs. 
IOSR Journal of Agriculture and Veterinary Science, issue 3, Vol. 9, Ver. I, pp. 20 - 22.

14. Hagan, J., 2018. The effects of breed, season and parity on the reproductive performance of pigs reared under hot and humid environments. Tropical Animal Health and Production, issue 51(4), p. 52. DOI: 10.1007/s11250-018-1705-5.

15. Huang, Y.H., Lee, Y.P., Yang, T.S. and Roan, S.W., 2003. Effects of Sire Breed on the Subsequent Reproductive Performances of Landrace Sows. Asian Australasian Journal of Animal Sciences, issue 16 (4), p. 7. DOI:10.5713/ajas.2003.489.

16. Knecht, D., Srodon, S. and Duziński, K., 2015. Breed on selected reproductive performance parameters of sows. Arch. Anim. Breed, issue 58, pp. $49-56$.

17.Kuhlers, D.L., Jungst, S.B. and Little, J.A., 1989. Comparisons of specific crosses from Duroc-Landrace, YorkshireLandrace and Hampshire-Landrace sows managed in two types of gestation systems: pig performance. J Anim Sci., issue 67 (10), pp. $595-602$.

18. Mungate, F., Dzama, K., Mandisodza, K. and Shoniwa, A., 2009. Some non-genetic factors affecting commercial pig production in Zimbabwe. South African Journal of Animal Science, Vol. 29. DOl:10.4314/sajas.v29i3.44202.

19. Sundruma, A., Aragona, A., Schulze-Langenhorstb, C., Bütferingb, L., Henningc, M. and Stalljohannb, G., 2011. Effects of feeding strategies, genotypes, sex, and birth weight on carcass and meat quality traits under organic pig production conditions. NJAS - Wageningen Journal of Life Sciences. issues 3-4, Vol. 58, pp. 163 - 172. DOl.org/10.1016/j.njas.2011.09.006.

\section{Mykhalko,O.G. \\ Povod, M.G.}

Reproductive qualities of sows of danish and french origin in the conditions of the industrial complex

This study compared the reproductive qualities of sows of French and Danish breeding during the year in the same farm. The results showed that animals of Danish origin had 16,02-18,73\% higher potential multiplicity during the year, with 1,07-1,57\% higher number of stillbirths. Danish sows had a higher multiplicity of $15,13-17,70 \%$ and had a greater number of piglets when weaned compared to their French breeding pigs by 14,21-15,82\%. At the same time, sows of French origin differed by $7,75-14,52 \%$ higher inbred and higher by 15,16-26,26\% by weight of one piglet when weaned. Piglets are not established by birth weight and weaned differences between groups of sows of different origin. The reproductive qualities of sows, both French and Danish, depended on the season. The least of the season depended: multiplicity of 3,68-4,37\%, preservation of piglets before weaning $3,32-5,34 \%$, number of piglets in weaning $-5,40-6,83 \%$. The individual mass of piglets when weaned was the most dependent on the changes of the seasons - 11,28-13,34\% and the mass of piglets' nests during this period - 12,74-17,49\%. More seasonal variability differed sows of Danish origin. The heaviest piglets were weaned from both sows in winter and the lightest in summer. The weight of the piglets' nests in both groups was higher in winter and spring compared to summer and autumn. Significant significant influence of the sows 'genetic identity on the weight of one piglet when $43,69 \%$ were weaned was established, the weight of the piglets' nests in this period was $40,39 \%$ and on the multiplicity of $19,13 \%$. The influence of sows' genetic identity on conservation has not been established. The season of the year had a much weaker effect on these indicators: $4,87 \%$ of the piglets' nests were weaned, $3,15 \%$ of the piglets were weaned, and $2,77 \%$ of the piglets were preserved. The impact of seasons on multiplicity has not been established. The interaction of sow genetic factors and seasons had a significant effect on: multiplicity of $47,22 \%$, weight of one pig when weaned $-43,60 \%$, weight of piglets' nest when weaned $-40,39 \%$, and preservation of piglets $-2,77 \%$. The index of comprehensive assessment of sows' reproductive qualities was $11,47 \%$ higher in Danish animals than in the French livestock population during the year.

Key words: sow, pig, genotype, season, reproductive qualities

Дата надходження до редакції: 25.06.2019 p. 